\title{
Rum, rammer og biblioteker i den virtuelle verden
}

\section{Simon B. Heilesen}

Lektor Mag. Art.

Roskilde Universitet.

Simon Heilesen er lektor i netbaseret kommunikation ved Institut for Kommunikation, Virksomhed og Informationsteknologier, Roskilde Universitet. Aktuelt koordinerer han opbygningen af universitetets IKT-Kompetenceudvikling og deltager desuden $i$ ledelsen af ELYK-projektet, der handler om netbaseret efteruddannelse af medarbejdere i små og mellemstore virksomheder i yderområder (http://www.elyk.dk). 


\section{Abstract}

Med udgangspunkt i en kort introduktion til hvordan rum og rammer gestaltes i den virtuelle 3-D verden Second Life, undersøger denne artikel, på hvilke måder rum og rammesætning anvendes og opleves i en faglig sammenhæng. Som eksempel anvendes det danske biblioteksprojekt i Second Life, Info Island DK. Ud fra en analyse af Information Archipelago, som er et område i den virtuelle verden med en høj koncentration af biblioteker, forsøger artiklen desuden at skitsere, hvordan design af biblioteker typisk gribes an i Second Life.

\section{Indledning}

Denne artikel udspringer af en undren over, hvorfor store dele af den virtuelle 3D-verden Second Life efter bedste evne søger at gengive den fysiske verden med alle dens begrænsninger. Metaforer kan være til stor hjælp i computergrænseflader, men de kan også virke begrænsende ved at binde brugeren for snævert og for systematisk til den fysiske verdens artefakter (Cooper 2003, s. 252 f.). Garvede internetbrugere vil måske huske, præcis hvor omstændeligt det var at bruge TDC's tidlige Opasiaportal med dens 3-D by-metafor.

$\mathrm{Nu}$ handler virtuelle verdener mere om oplevelser og samvær end om informationssøgning, kan det hævdes. Alligevel spiller søgning og formidling af information en ikke-ubetydelig rolle i en verden som Second Life. I den sammenhæng giver det mening at spørge om, hvilke muligheder en tilstræbt naturalistisk gengivelse af den fysiske verden tilbyder, og hvad den afskærer brugeren fra? Disse spørgsmål kan ikke besvares éntydigt, netop fordi der er tale om en "verden" med umådelig mangfoldighed. Men de kan belyses med et eksempel, vel vidende at dette naturligvis ikke er generalisérbart. Som eksempel anvendes en formidlingsinstitution, biblioteket, der er velkendt fra den fysiske verden, og som allerede har bevist, at dens funktioner med stor succes kan udføres via internettet. Som udgangspunkt redegøres for erfaringerne med det danske projekt Info Island DK, der er et af de større offentligt støttede danske initiativer i Second Life. Dernæst forsøges defineret en typologi for design af Second Life biblioteker. Indledningsvis skal kort redegøres for rum og rumlighed i netmedier generelt og i Second Life specielt.

\section{Form i intetheden}
"Cyberspace ...is the global domain of electro-magnetics accessed through electronic technology and exploited through the modulation of electromagnetic energy to achieve a wide range of communication and control system capabilities."
(Wikipedia, 2008)

Wikipedias definition af ordet "cyberspace" er blot én blandt mange. Den er gengivet her, fordi den med en teknologisk tilgang beskriver et fænomen, der er så abstrakt, at det er meget vanskeligt at fatte for almindelige mennesker. Såvel cyberspace som internettets "rum" - der indgår i men er ikke identisk med cyberspace - og de virtuelle verdeners rumlighed har da også alle været genstand for en del forskellige analyser (bl.a. Anders, 1999; Qvortrup, 2002; Snowdon, \& al., 2004; Tække, 2008). 


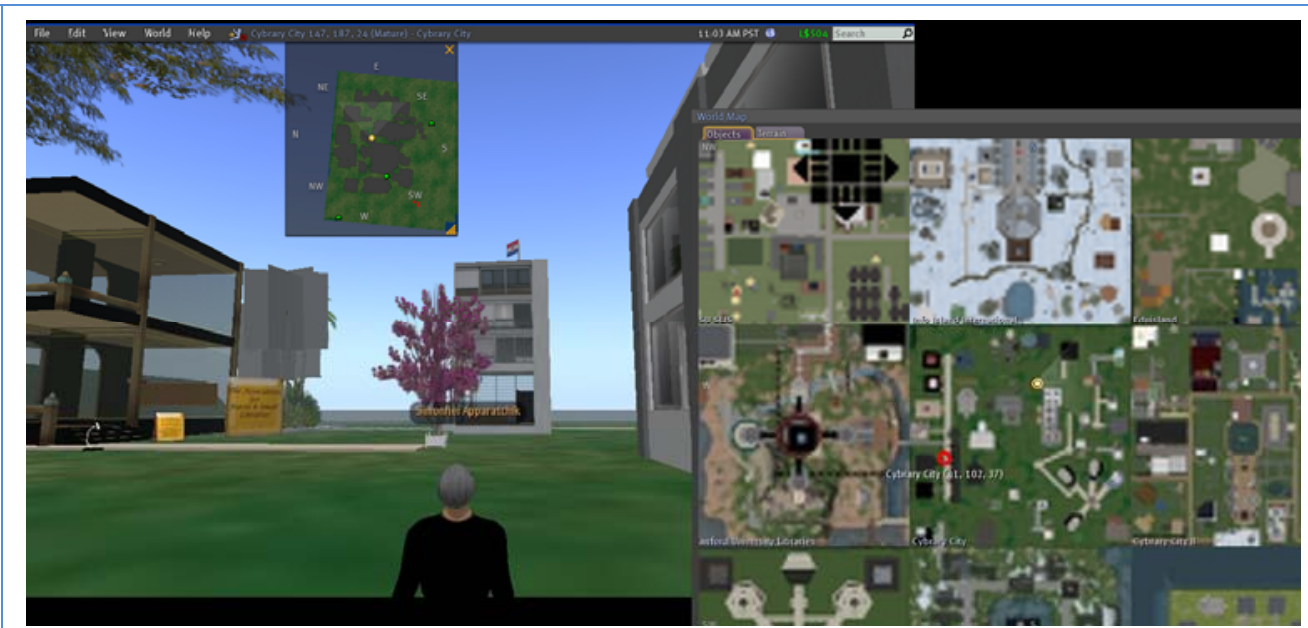

Figur 1. 3-D og 2-D navigation. Cybrary City. For oven i 3-D billedet et "mini-map" til orientering. Til højre et detaljeret kort over området.

I denne artikel er udgangspunktet imidlertid ikke rumbegrebet som sådan. Det skal handle om visualiseringen af rum i den konkrete brugssituation, eksemplificeret med biblioteker i 3-D virtuelle verdener. En sådan konkret udnyttelse af rum betegnes gerne som et "sted". Et sted i en virtuel verden er defineret ud fra et sæt koordinater og nogle regler, som fastlægger (virtuel) udstrækning og egenskaber. Men en stor del af pointen ved en virtuel verden som Second Life er, at den enkelte oplever at være i stand til at indrette og agere i sit eget, lokale, konkrete sted midt i verdenens abstrakte rum. Som det fremgår nedenfor, opfatter brugerne da også Second Life biblioteket som et sted. Betegnelsen "rum", i betydningen snævert afgrænset ramme om aktiviteter (det oplevede rum som er en del af stedet) bibeholdes imidlertid i den aktuelle sammenhæng, og dette valg begrundes i det følgende.

"Verden" omfatter i denne sammenhæng ikke hele "den virtuelle verden", som i øvrigt ikke er en verden, men derimod en model (Aarseth, 1996). Artiklens "verden" er den model, brugeren oplever på computerskærmen, dvs. en komposition, der skaber en ramme for interaktion med objekter og brugerne imellem. Rammen kan anskues rent bogstaveligt som et billede eller en scene, der kan forstås i en kunsthistorisk sammenhæng (Bachhofer, 1946; Gombrich, 1960), eller den kan forstås som en fortolkningsramme for den kommunikation, der finder sted (Goffman, 1974).

\section{Second Life rum og rammer}

Computerbrugergrænsefladens historie handler om visualisering af det abstrakte "rum" af elektromagnetiske impulser, som citatet ovenfor beskriver. Cyberspace er ingen undtagelse. Forfatteren William Gibson (1984), der i sin tid skabte begrebet, kaldte cyberspace for en "hallucination" og for en "grafisk repræsentation af data". Dermed tager han, og mange andre med ham, udgangspunkt i en billedlig fortolkning af eller anden form for genkendeligt rum, som gør det lettere at fatte fænomenet. Cyberspace skildres ofte grafisk ud fra den fysiske verdens konventioner for kartografi og for afbildning af fysiske rum (Dodge \& Kitchin, 2001), mens det i rene tekstbaserede brugergrænseflader er 
almindeligt at benytte metaforer som "rum" (i betydningen stue) og "hus" for afgrænsede dele af et netbaseret computersystem.

3-D virtuelle verdener, og blandt disse Second Life, byder på en grafisk avanceret anskueliggørelse af cyberspace. Netop denne bidrager til at gøre den virtuelle verden attraktiv. Det er underforstået i selve terminologien, "virtuel verden" og "Second Life", at der er tale om noget, der med genkendelsens tryghed omslutter brugeren og lader ham agere (i det mindste delvis) på den fysiske verdens præmisser. Om det så er bedre eller blot lige så godt - at chatte på torvet i den virtuelle købstad Wonderful Denmark, som det er at chatte på NetDating.dk, tager denne artikel ikke stilling til. Den handler kun om de rammer, som interaktionen foregår i.

I en virtuel verden som Second Life forekommer to forskellige gengivelser af rum: en 2-D gengivelse af topografien - en art "landkort", og en 3-D gengivelse af det rum, som brugerens virtuelle repræsentation, avataren, bevæger sig i (Figur 1). Denne dobbelthed har en pendant i computerspillene, ikke mindst i on-line multiplayer spillene. Den er nødvendig, fordi det i praksis er overordentligt vanskeligt at bevare orienteringen i en virtuel verden udelukkende ved hjælp af 3-D gengivelsen - uagtet at det er et af argumenterne til fordel for 3-D verdener, at det angiveligt er noget iboende menneskeligt at opleve rumligt (Anders, 1999).

I spillenes verdener kan man skelne mellem to former for topografi. I nogle af dem udgøres verdenen af én sammenhængende flade med en logik (men ikke nødvendigvis en skala), der svarer til den fysiske verden. I andre udgør topografien en hypertekst, hvor brugeren på sin færd springer fra scene til scene, uden at disse nødvendigvis grænser op til hinanden.

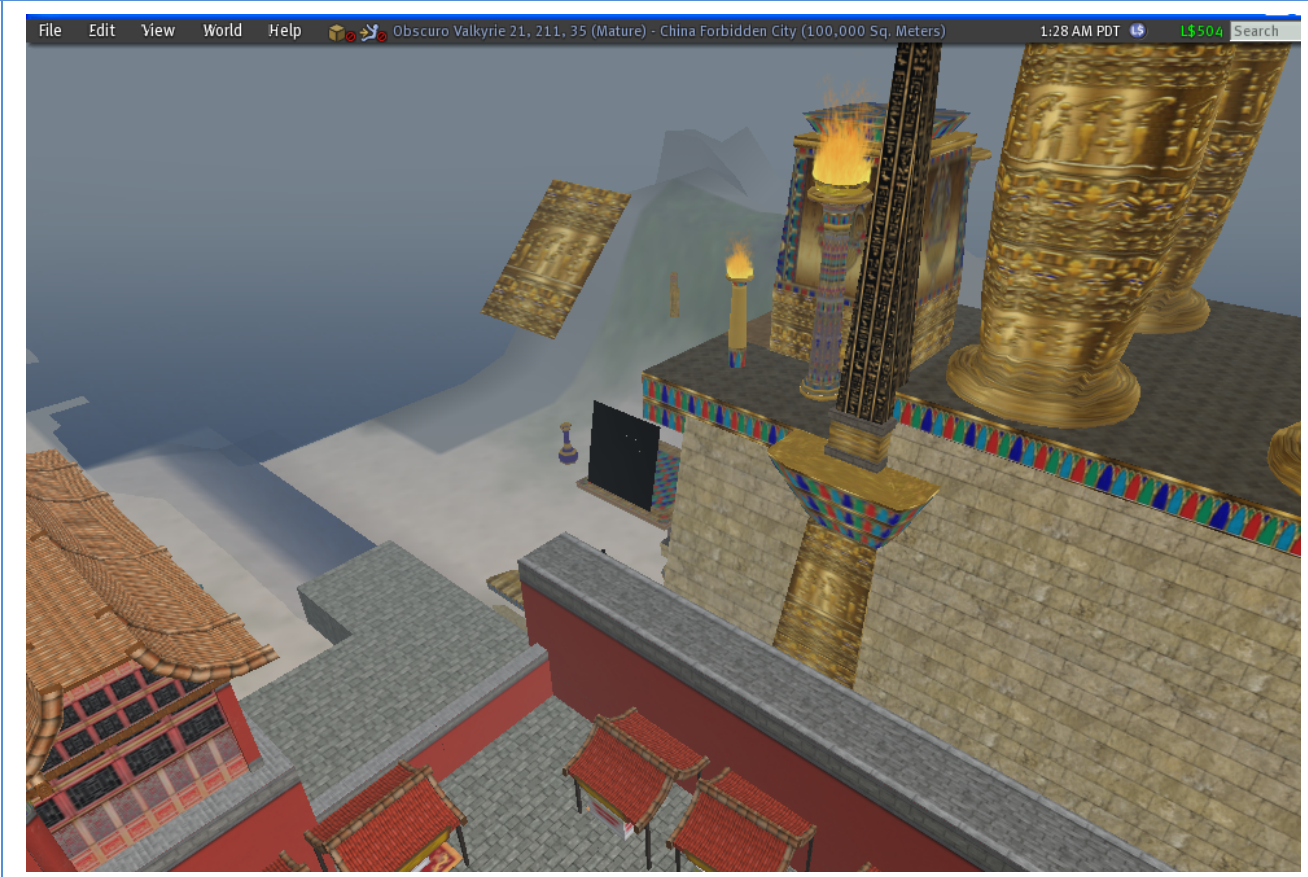

Figur 2. Her grænser den Forbudte By i Beijing op til et oldegyptisk tempel. Der er ikke nødvendigvis kontinuitet mellem mellem regioner og parceller. De udgør hver især et episodisk rum. 


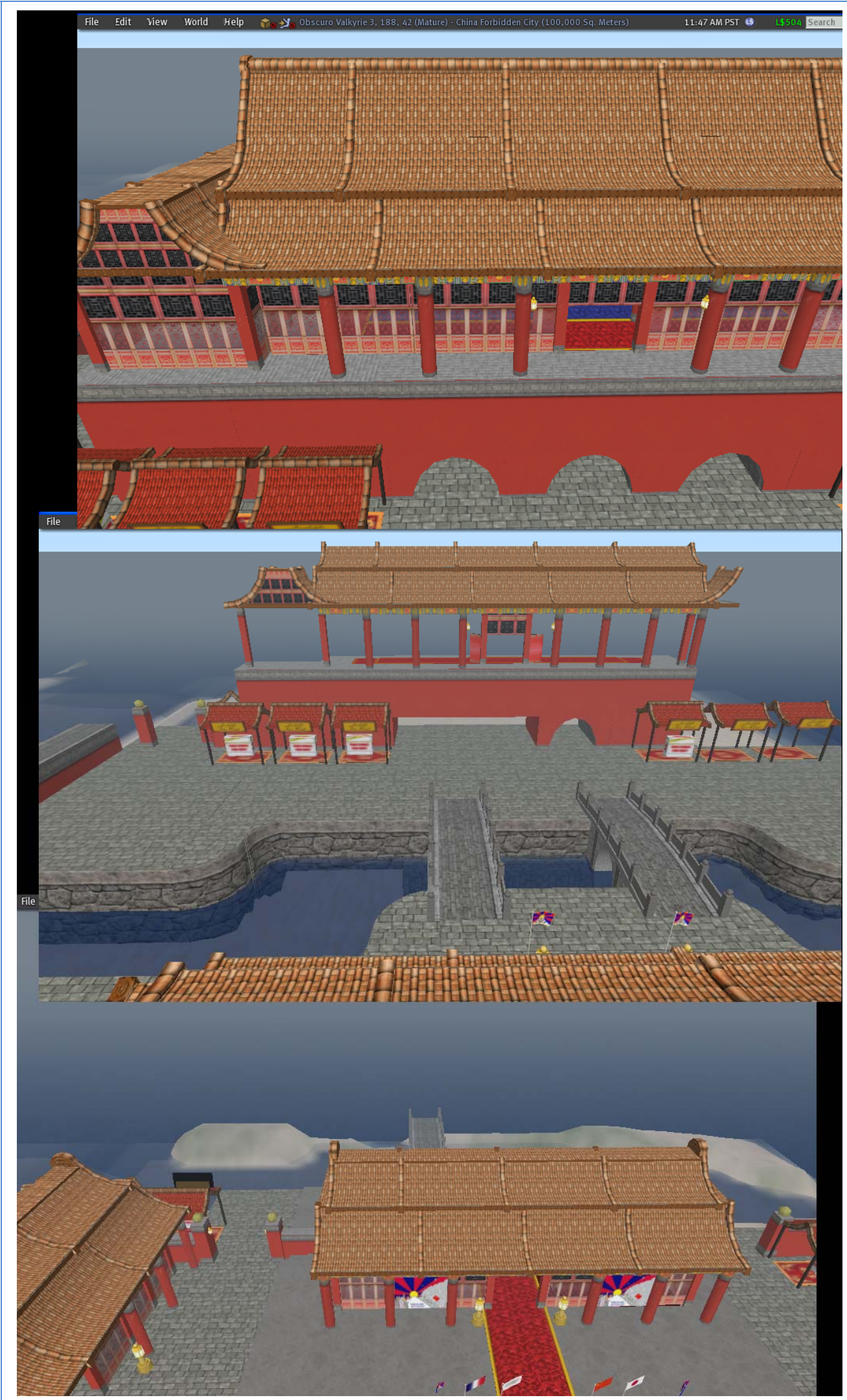

Figur 3. Rumligheden begrænses af, at kun nære objekter er fuldt synlige på skærmen. 
Topografien i Second Life adskiller sig fra begge disse. Godt nok er der i Second Life et "fastland" bestående af "regioner", der er inddelt i større og mindre parceller, og en myriade af øer (hver især en region). Men helheden, the grid, er i modsætning til de fleste spil under konstant forandring, og forandringen er primært brugerstyret og derfor ikke forudsigelig. Der er ikke nogen given geografisk eller tematisk kontinuitet mellem de enkelte regioner og disses parceller, og heller ikke øerne imellem - bortset, naturligvis fra, at ejeren af flere sammenhængende regioner kan vælge at opbygge dem med en overordnet topografi (Figur 2). Endelig er der heller ikke nogen narrativ kontinuitet, som det er tilfældet med hypertekst-landskabet. En lokalitet i Second Life kan fylde mere eller mindre, men den er normalt enkeltstående, såvel topografisk som indholds- og oplevelsesmæssigt. Den skaber sit eget, unikke rum for brugeroplevelsen - et episodisk rum.

Dette episodiske rum oplever brugeren som et 3-D rum, når han teleporterer (navigerer) sig frem til en lokalitet. Kun de umiddelbare omgivelser på lokaliteten gengives i detaljer. Objekter, der er længere væk gengives delvist eller slet ikke. De renderes først, når brugeren bevæger sig frem mod dem (Figur 3). Denne indbyggede "nærsynethed", som skyldes et praktisk hensyn til forbruget af maskinkraft, udgør en ret voldsom begrænsning af rumligheden. Brugeren kan kun orientere sig visuelt og dermed kommunikere visuelt inden for en forholdsvis beskeden radius.

"Talerummet" er mere vidtrækkende end det afbildede rum. Når brugeren chatter, transmitteres hans ord således ud i en radius på 20 meter (96 meter hvis han "råber") uanset hvilke barrierer (vægge, døre), der måtte optræde i rummet. Til sammenligning udgør en hel region et kvadrat med en side på 256 meter, mens den mindste parcel udgør et kvadrat med en side på 22,6 meter. Mellem "venner" er talerummet imidlertid ubegrænset, idet man kan udveksle beskeder på tværs af alle geografiske skel med andre on-line-brugere, som man har oprettet et venskab med.

Rumlighed og rækkevidde, som de er beskrevet ovenfor, opleves som forskellig fra den virkelige verden og kræver tilvænning, som det fremgår af denne beretning fra en Info Island DK bibliotekar:

"... på et tidspunkt havde vi inviteret en hel masse avatarer fra hovedbiblioteket derind. Det var deltagere i et uddannelsesforløb, der hedder 23 Ting. ... Jeg havde forberedt mig meget på, at jeg ville gerne vise dem rundt i huset ... Men det viste sig at være en meget svær opgave, fordi de, nogle af dem var nybegyndere, og andre var avancerede, og de myldrede rundt over det hele.... Og da jeg sagde, 'kom med herhen, så skal jeg vise jer', så var der halvdelen af dem, der ikke kunne finde ud af at følge med. Og så kunne jeg høre, de stod omme på den anden side af auditoriet og sagde, 'hvor gik hun hen' og 'nu er hun gået' ... De kunne stadigvæk godt læse på skærmen, hvad jeg skrev ... Men de kunne ikke alligevel rigtig få noget ud af det, åbenbart fordi min avatar var gået væk fra dem, og de kunne ikke se avataren. Og så var kommunikation altså afbrudt på grund af det. Så det var en ... meget god oplevelse af, hvordan ... at selv om man har 
nogle helt nye måder at kommunikere på derinde, og egentlig ikke

behøvede at have så meget den her rigtige afstand og have face-to-

face og lige akkurat stå stille der, mens nogen taler, ... Så er det

alligevel en ...basal forudsætning for, at man føler, at man har en

fornuftig dialog sammen."

(interview med Dorthe)

Langt de fleste lodsejere i Second Life vælger at bebygge deres grund. Dermed skaber de inddelinger i form af bygninger, veje, pladser og haver, hvor brugernes interaktion med objekter og med hinanden kan finde sted. Byggestil og systemets "nærsynethed" går hånd i hånd om at skabe nære rammer, så interaktionen typisk foregår i et afgrænset rum, der giver mindelser om den form for kompositorisk indramning, som kendes fra billedkunsten. Rummet er ikke statisk. Man kan bevæge sig gennem det og ind i og igennem andre rum, der alle kan anskues fra mange forskellige vinkler. Et besøg i en Second Life region er typisk en rejse i tid og rum. Helheden afsløres gradvis gennem udforskning af de enkelte dele, der hver for sig gerne danner lokale rum af forskellig beskaffenhed. Denne form for "rejse i motivet" kan give mindelser om den østasiatiske billedrulle (japansk: makimono), hvor kun en lille bid af den samlede komposition er synlig på et givet tidspunkt, og hvor handlingen udspilles gennem forskellige delkompositioner med vekslende perspektiv. At "læse" en billedrulle er en oplevelse, der kræver tid og indlevelse. Der opbygges stemninger og skabes antydninger, som læseren kan arbejde videre med. Der er et stykke vej fra det forfinede orientalske landskabsmaleri til Second Life's tableauer, men glæden ved at udforske en verden og lade sig rive med af scenerierne er helt klart en af attraktionerne også ved Second Life.

Rum i Second Life kan som nævnt opfattes helt bogstaveligt som iscenesættelsen af aktiviteter. Bachhofer (1946) skabte i sin tid ordet "rumcelle" (space cell) om kompositorisk indramning af motiver i kinesisk maleri. Men rumceller optræder også meget hyppigt i vestligt, figurativt maleri fra antikken og op til nutiden. Ud over at skabe en kompositorisk ramme for handlingen inden for billedrammen tjener de til at levere en forståelsesramme og til at anslå en stemning. I dette er der lighedspunkter med den form for ramme (frame), der i kommunikationsvidenskab optræder som fortolkningsramme for kommunikationshandlingen (Goffmann, 1974). I det følgende diskuteres eksempler på rammer for den form for interaktion, der knytter sig til biblioteker. Men inden da nogle få kommentarer til den stilistiske udformning af rammerne.

\section{Second Life naturalisme}

I en virtuel verden som Second Life afbildes bogstavelig talt alt mellem himmel og jord. Men den stilistiske ensartethed er alligevel påfaldende. Der synes at være et fælles skema (engelsk schemata; Gombrich, 1960) for, hvordan man vælger at skildre den virtuelle virkelighed. Skemaet synes at bygge på computerspillenes verden. Men gennemgående lægges der i Second Life særlig vægt på, at tingene skal ligne den fysiske verdens objekter. Det er en stræben, der er forståelig som et forsøg på at skabe velkendte og trygge rammer at agere i, og det er også et udtryk for programmeringsfærdigheder, at man kan få tingene til at ligne. Men det 
lægger samtidig en dæmper på den kreative og innovative udfoldelse, som er mulig i en virtuel verden, og som måske kan åbne for nye måder at gøre tingene på. Innovation er at gøre noget andet, end man plejer, og det er vanskeligt, som en bibliotekar fremhæver i sin beretning om at skulle skabe inventar til det virtuelle bibliotek:

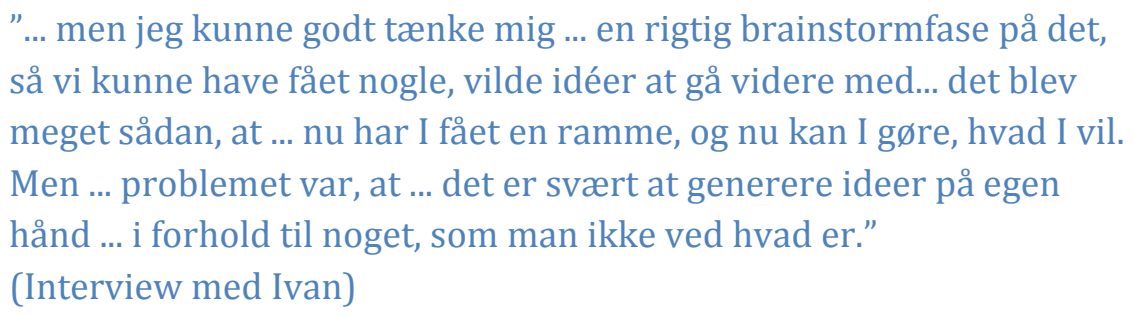

Megen litteratur om virtuelle verdener taler om den "realisme", det er muligt at opnå i en verden som Second Life. Men det giver nok mere mening at tale om naturalisme i en idealiseret form. Der er langt mellem det trøstesløst hæslige og det kompromisløst usminkede visuelle udtryk i Second Life. Landskaber, bygninger, objekter og avatarer er som oftest nydelige, og selv det grimme er nogenlunde friseret, uskadeligt, og ligesom alt andet skildret i pastelfarver, der tones smukt i solopgangens og solnedgangens varme skær - som sammen med middag og midnat udgør den tidsmæssige rammesætning. Det er enklere at bygge med plane flader, ubrudte linjer og symmetriske former, end det er at illudere ufuldkommenhedens og grimhedens snavs, forfald og skurrende, kantede former. Der er således rent praktiske grunde til, at byggeriet i Second Life gennemgående skildrer en pæn og ordentlig verden. Men implicit synes der alligevel at herske udbredt enighed om, at den virtuelle verden ikke nødvendigvis behøver præcist at gengive den fysiske verdens mest uflatterende sider. Der er i hvert fald langt imellem tilstræbt grimme scenerier i Second Life.

Fordi alting enten er nogenlunde tæt på, eller også ikke gengives, er der ikke den store dybde i Second Life's rum, men perspektiv, schattering og størrelsesforholdene mellem det nære og det fjerne skaber en udtalt 3-D effekt. Skyggelægning bruges i øvrigt kun til at opbygge former, mens objekterne i Second Life kun undtagelsesvis kaster skygger og slet ikke systematisk i forhold til en lyskilde. Lyskilden er dog ofte gengivet ved, at objekter belyses forskelligt i solopgang og solnedgang, men ellers forekommer lyset i Second Life noget diffust. De fleste rum er konstrueret mere højloftede, end tilsvarende rum ville være i den fysiske verden. Men størrelsesforholdene virker naturlige, fordi øjepunktet ligger meget højt, bagved og over brugeravatarens hoved. Brugeren svæver så at sige bag sin avatar, når han bevæger sig gennem den virtuelle verden.

\section{Biblioteket som ramme}

Det empiriske grundlag for denne artikel stammer fra en undersøgelse af erfaringerne med det danske biblioteksprojekt Info Island DK, som løb fra marts 2007 til udgangen af samme år (for en projektbeskrivelse, se Borgerservice og Biblioteker, 2007). Undersøgelsen har dels omfattet interviews med 11 af de i alt 20 personer, som var involveret i projektet, dels en systematisk gennemgang, rum for rum, i forsommeren 2008 af 
samtlige virtuelle biblioteker i det område af Second Life, der går under betegnelsen Information Archipelago ("Informationsskærgården"; se nedenfor). Det skal bemærkes, at der også findes biblioteker andre steder i Second Life. Men eksemplerne fra Information Archipelago, hvoraf en del har været toneangivende, må formodes at være illustrative for, hvordan virtuelle biblioteker typisk konstrueres.

Om Info Island DK (http://slurl.com/secondlife/Info\%20Island\%20DK/ 128/128 /0;) er der udgivet en afslutningsrapport (Barlach, 2008), en kort evaluering (Gotved, 2008), et mindre antal artikler i biblioteks-fagblade (Hald, 2007; Hald, 2008; Knudsen \& Olsen, 2008; Mortensen, 2007; Pedersen 2007a \& 2007b), en film (Barlach \& Larsen, 2008), et working paper (Heilesen, 2008) samt to artikler om projektet med fokus på kulturformidling (Heilesen, 2009; Heilesen, 2010). Desuden er projektet rigt dokumenteret med illustrationer i Flickr (tag: Info Island DK).

Hvorfor så lige biblioteker? Dels fordi Info Island DK er et af de hidtil største danske forsøg med at oprette offentlige tjenester i virtuelle verdener. Dels fordi biblioteker har bestemte, velkendte funktioner. Dels fordi biblioteket er et godt "rum". Det er noget, alle kender og kan forholde sig til; og der er det særlige ved "biblioteket", at det både er et begreb, en institution, og et sted. Det har symboliseret civilisation siden antikken startende med Alexandria biblioteket. Det har været et synligt vidnesbyrd om kirkens og herskernes magt og oplyste styre - tænkt blot på Vatikanbiblioteket, de store fyrstelige samlinger og nationalbibliotekerne. Og i nyere tid har det stået for demokrati, frihed og lighed for alle i adgangen til viden. Biblioteket er et magtfuldt begreb, som sætter fantasien i gang - fx i de fortællinger nutidsforfattere som Jorge Luis Borges (La biblioteca de Babel) og Umberto Eco (Il nome della rosa) har skabt. Bibliotekets bygninger har understreget institutionens betydning. Eldre tiders biblioteker ligner ofte paladser, katedraler og templer. Blandt nutidens bygninger findes adskillige eksempler på fremragende bygningsværker, tegnet af ypperlige arkitekter. Med et sådant tankegods er det ikke nogen helt ubetydelig opgave at skulle genskabe biblioteket i en virtuel verden.

Som institution udmærker biblioteket sig ved at være til rådighed for alle både fysisk og virtuelt. Bibliotekerne har klaret sig forbløffende godt $\mathrm{i}$ informationsalderen ved at gå i spidsen for udnyttelsen af netmedierne og opbygge services som online-kataloger og online-betjening, som gør livet meget lettere for brugerne. Alle spådomme om, at den teknologiske udvikling vil reducere bibliotekerne til rene magasinbygninger er hidtil gjort til skamme.

Danske biblioteker har en del af æren for at udbrede kendskabet til internettet, World Wide Web, og senest det sociale net, det såkaldte Web 2.0. Både herhjemme og i udlandet har bibliotekerne påtaget sig rollen som pionerer i at afprøve og formidle ny teknologi. Derfor har det også været en naturlig opgave for bibliotekerne at afprøve de nye virtuelle verdener, specielt Second Life, der efter sin start i 2003 i løbet af få år blev genstand for intens interesse. De første biblioteker etablerede sig i denne virtuelle verden i foråret 2006 (Bell, \& al., 2007; Bell, \& al., 2008). De blev fulgt af 
mange andre, blandt dem det danske projekt Info Island DK, som blev etableret af seks danske folkebiblioteker i 2007. Mange af de virtuelle biblioteker slog sig ned i et bestemt område af Second Life, der er blevet kendt som Information Archipelago. Området, som også huser adskillige virtuelle uddannelsesinstitutioner, bestod på undersøgelsestidspunktet (sommer 2008) af en halvt hundrede øer, nogle af dem med mange institutioner repræsenteret. En opgørelse fra det amerikanske Info Islandprojekt opregner ved udgangen af 2008 mere end 130 Second Life biblioteker (Second Life Library Project, 2008).

Selv om det måske giver mening at have mange biblioteker samlet på ét sted i en virtuel verden, som det er svært at orientere sig i, så er det alligevel tankevækkende, at en meget stor del af bibliotekerne i Second Life har valgt at klumpe sig sammen på en lille gruppe af øer. Det er svært ikke at tolke denne frivillige ghettoisering som noget lidt indadvendt, som om de virtuelle biblioteker henvender sig lige så meget til hinanden som til publikum. En af konsekvenserne har været en cementering af den konventionelle opfattelse af, at biblioteket er en institution og et sted, som publikum skal opsøge, og som er adskilt fra arbejds- og fritidslivets mange gøremål.

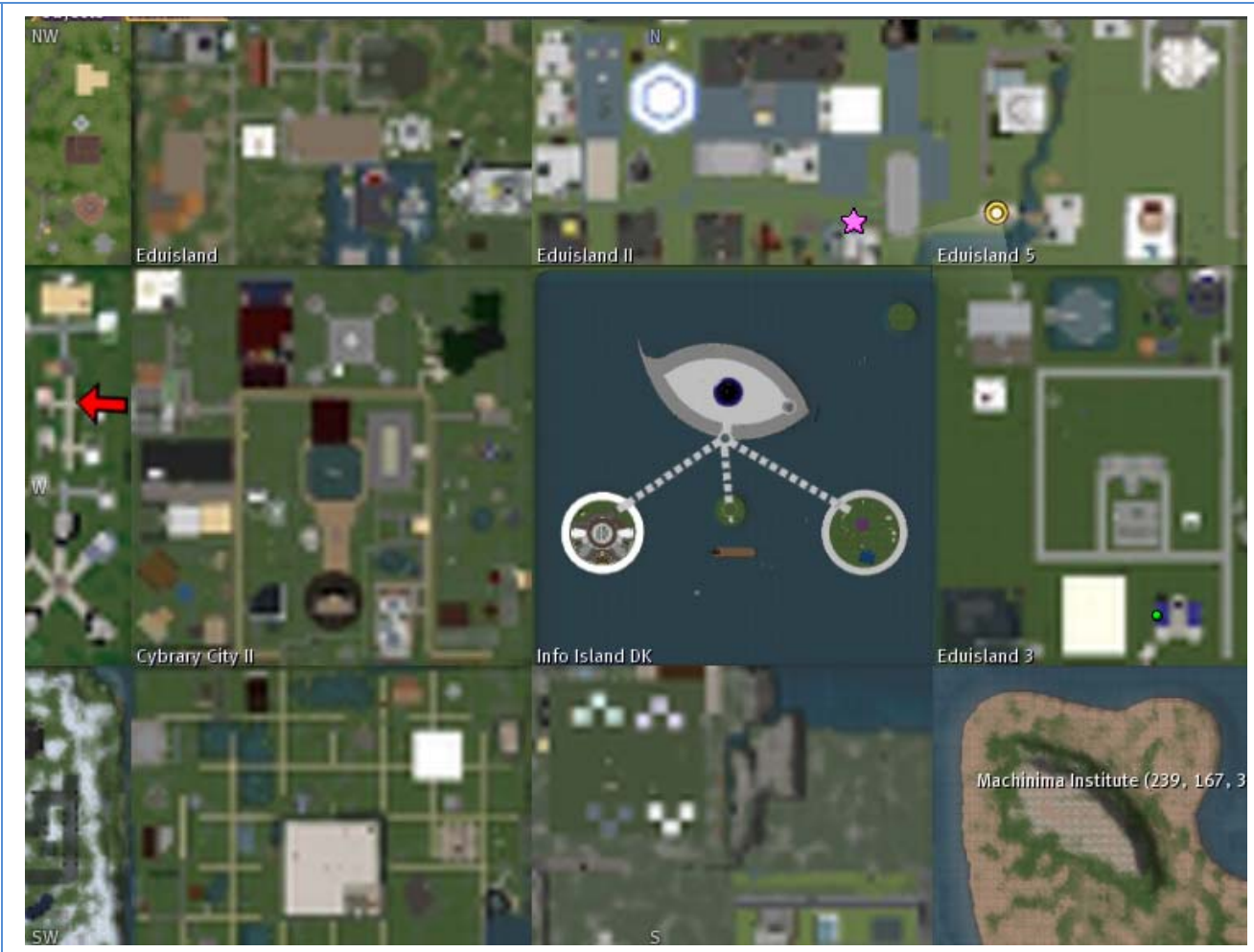

Figur 4. Info Island DK med omgivende øer i Information Archipelago. Sommer 2008.

\section{Info Island DK}

Info Island DK lå, mens øen var aktivt i brug, centralt placeret i Information Archipelago. Den er tegnet af arkitekterne Stig Retpen og Peter Rhode fra 
Stadsarkitektens Kontor i Århus og konstrueret i Second Life af Århusvirksomheden FutureCom. Der er således tale om et helt igennem professionelt arbejde og om et originalt design af høj kvalitet.

Regionen, som er den tekniske betegnelse for en " $\varnothing$ ", er opbygget af i alt fire småøer, hvoraf de tre er indbyrdes forbundne med broer (Figur 4). Midt i regionen ligger ankomstplatformen, hvorfra en bro fører nordpå til den ovale $\emptyset$, som rummer Formidlingshuset. Fra denne ø udgår broer til to mindre, cirkulære øer. Mod øst, på højde med ankomstplatformen, ligger Playground, en ø indrettet som "sandkasse", hvor alle besøgende har lov til at bygge. Mod vest ligger Infotainment. Denne ø blev i november $2007 \mathrm{blev}$ overdraget til det norske Vestfold Fylkeskommunes Bibliotek. Mod nordøst i regionen ligger den lille, nu ubebyggede Pims $\emptyset$, opkaldt efter Info Islands programmør. Under havet ligger et par magasinbygninger samt et tunnelsystem. Tunnellerne, som nu til dels er fjernet, var programmørernes private legeplads, og de indgik ikke i projektet. Dog har Ames' Bar, som lå i den sydvestlige ende af tunnelkomplekset spillet en vigtig, uformel rolle som samlingssted (Figur 5).

Formidlingshuset, som er Info Island DK's centrale bygningsværk, har form som et øje, hvor bygningens ydermure definerer øjenæblet og den udækkede skakt midt i bygningen udgør pupillen. Det er en grundplan, som inviterer til fortolkning. I afrapporteringen (Barlach, 2008) tales der således om, at formen symboliserer udsyn og indsigt. Men faktisk udspringer designet af et ordspil, hvor arkitekterne har moret sig med tanken om at skulle skabe en Info "eye" Land (Island).

Øen er formet som en platform af sten. Der er terrasse hele vejen rundt om Formidlingsbygningen, og mod øst er opført et lille udendørs amfiteater, der vender ud mod en storskærm, der kan glide op fra vandet. Huset er i to etager og har form som en omvendt keglestub (Figur 6). De svagt udadskrånende vægge giver bygningen et let præg, som yderligere understreges af de ovale glaspartier, der udgør størstedelen af facaden. De giver byggeriet et maritimt anstrøg, som accentueres af en glasterrasse, der som en kommandobro afslutter taget mod øst. Dannebrogsflaget på taget agter må siges at høre til metaforen, men det passer ikke godt ind i stilen. Glasfacaderne giver et godt indblik i bygningen, der virker langt mere indbydende end flertallet af de klodser, der gør det ud for huse i Second Life. Lyset inde i huset er fremragende, og den besøgende føler sig i god kontakt med den omgivende natur. Bygningens terrasse og mure er holdt $\mathrm{i}$ lyse, grå toner og gulvene er røde, så hele bygningen fremtræder i de nationale farver. 


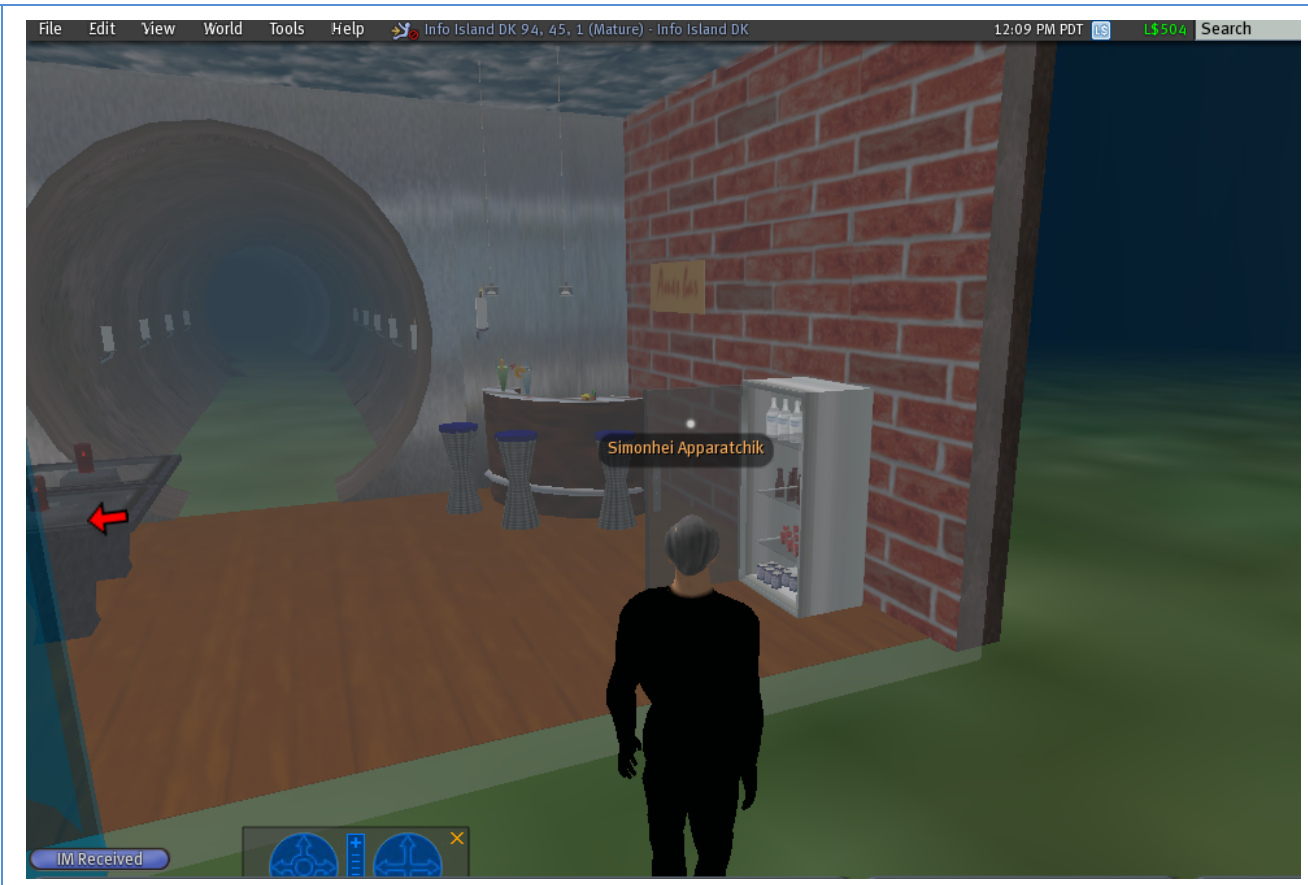

Figur 5. Ames' Bar. Sommer 2008.

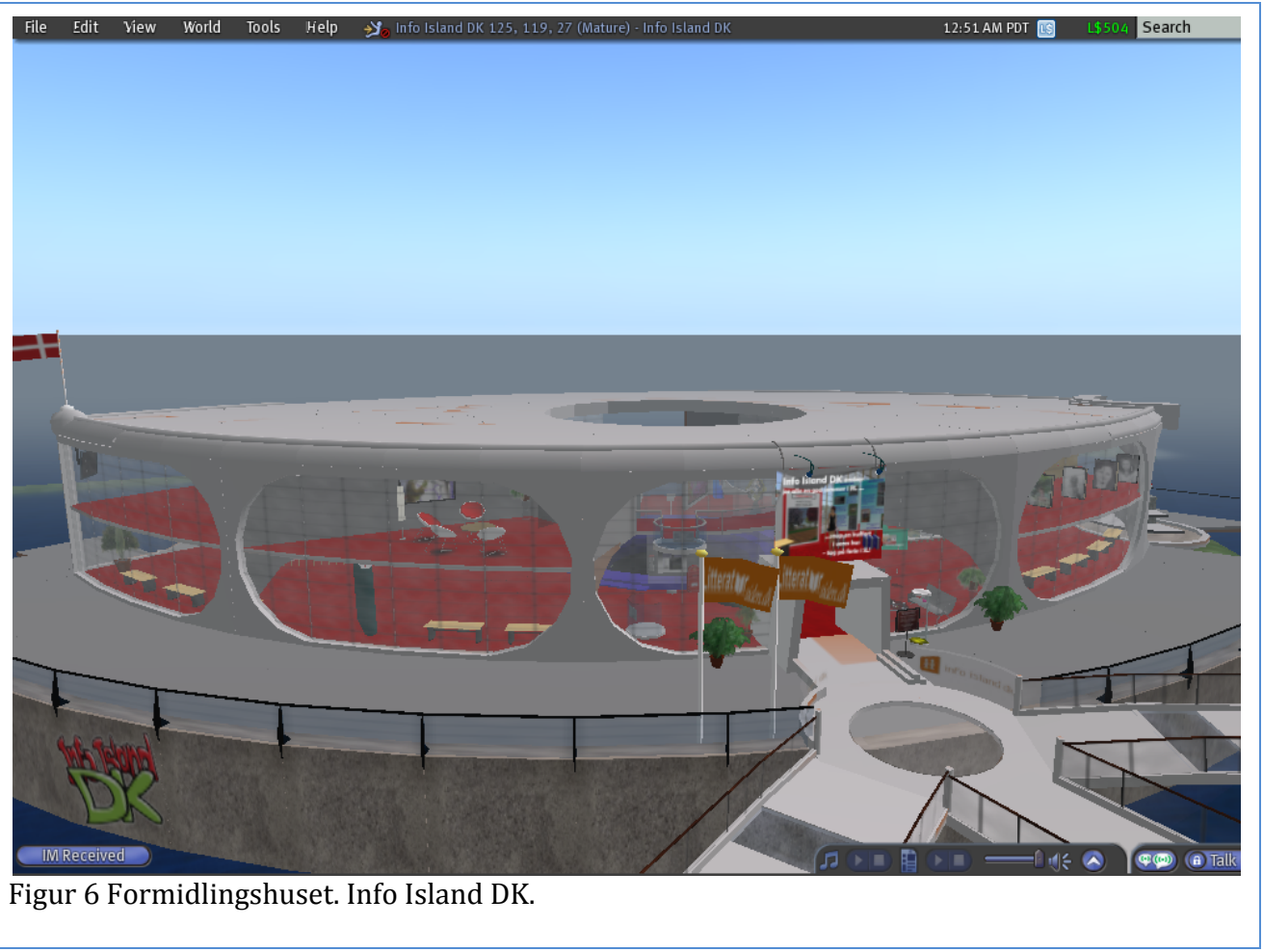

Stueetagen er udformet som åbent plan omkring en polygonal skakt med glasvægge, i hvis bund er indrettet et stort auditorium med tilhørerpladser i tre niveauer. Auditoriet er udført med mørke farver, som illuderer det dæmpede lys i en foredragssal (Figur 7). Flytbare lamelvægge gør det muligt at opdele stueetagens store og højloftede rum i sektioner til udstillinger. 


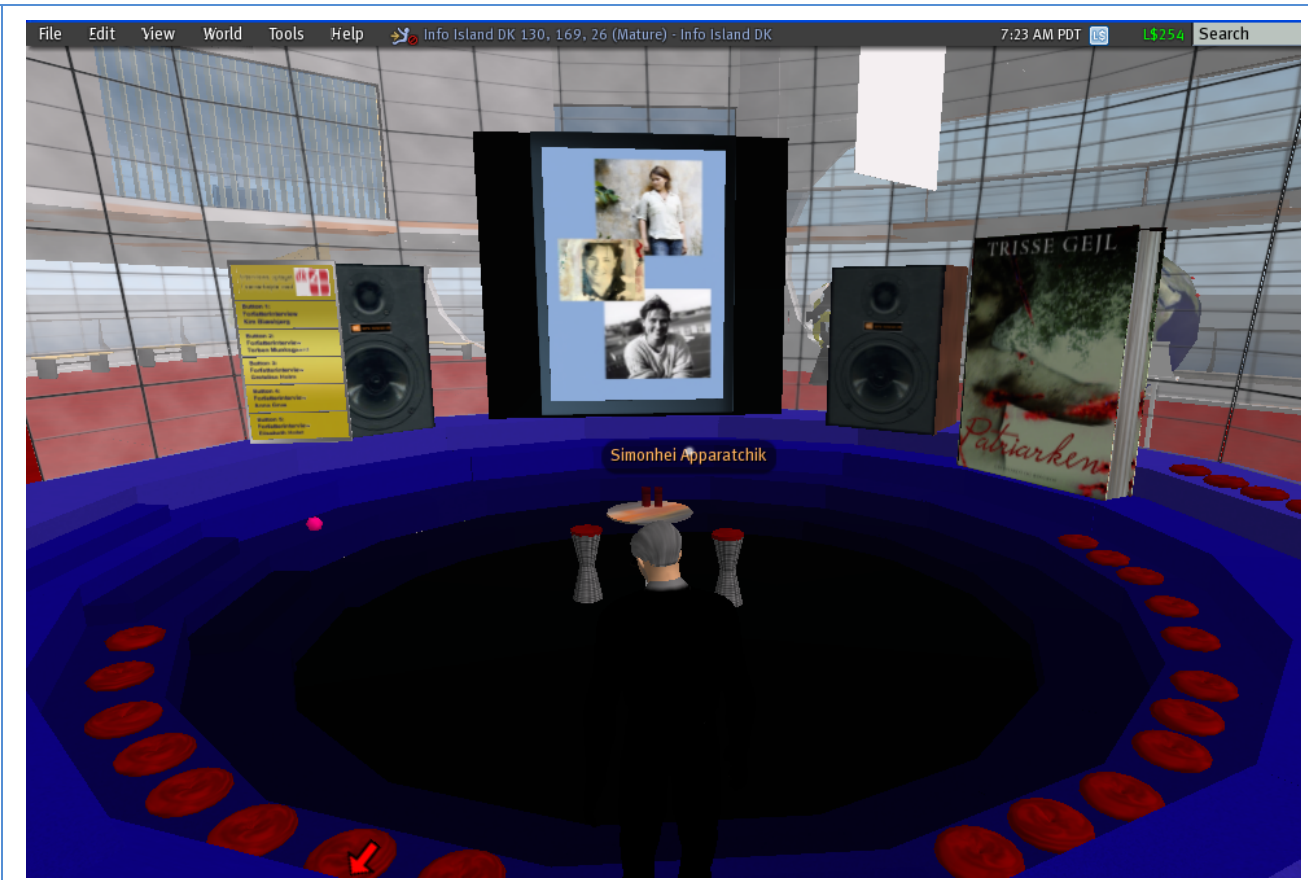

Figur 7. Auditoriet. Formidlingshuset. Info Island DK..

Husets vægge, gulve og glaspartier er "faste", og man går ind gennem hovedindgangen, eller man flyver ned gennem skakten til auditoriet. Der er kun adgang til første sal via en teleporter, som er opstillet til venstre for indgangen. Det er en svaghed ved bygningen, at der er så vanskelig adgang til første sal. Men i det mindste har bygmestrene undgået at opføre en trappe. Trapper giver ikke megen mening i en verden, hvor avatarerne kan flyve, men der er alligevel mange af dem i Second Life.

Første sal er indrettet med en korridor omkring den centrale skakt. På udsiden af korridoren ligger en række større og mindre rum, nogle af dem forsynet med døre, der kan lukkes. Der er således et udstillingslokale, et kontor, et stort mødelokale og to mindre rum, der ville kunne anvendes som mødelokaler. Af disse rum er det kun mødelokalet, som har været i regelmæssig brug.

\section{Oplevelsen af biblioteket}

Om baggrunden for byggeriet fortæller projektejeren:

\footnotetext{
"Jeg har en baggrund som kontorchef på Stadsarkitektens Kontor i

Århus. Derfor var det helt naturligt, at betragte opgaven med at skulle

"bygge" et virtuelt bibliotek som en almindelig planlægnings- og projekteringsopgave, og derfor involvere kommunens arkitekter i opgaven. Vi drøftede i projektet forinden om vi i det hele taget skulle have et hus, når det nu var muligt at gå helt nye veje, men enedes $\mathrm{i}$ projektgruppen om, at det ville være mest hensigtsmæssigt at forsøge at lave en flot ramme."

(interview med projektejer)
} 
Fra starten var Info Island DK således tænkt som en virtuel udgave af en fysisk biblioteksbygning, udformet i overensstemmelse med traditionen for pragtbyggeri. Ikke alle har fra starten været lige begejstrede for at kopiere virkelighedens byggeri. Men det viste sig at være den lette løsning. Desuden går der også let lidt sport i at bygge flot:

"... og det var en udbredt holdning, at man ikke skulle kopiere det bibliotek, man kender i dag, for hvorfor skulle man det? Altså, så var der ikke nogen grund til at gå ind i virtuelle rum. Og det var lige fra bygningerne, altså hvorfor skal der være tag på et hus, altså, det er jo egentlig ligegyldigt, og man gjorde egentlig meget ud af at kopiere fysiske bygninger i den måde, det blev konstrueret på. Og man tænkte egentlig også ret langt hen ad vejen ret traditionelt. Men det var hele tiden, man sådan diskuterede. Det var ikke fordi, man nødvendigvis syntes, at det skulle være sådan, det er bare så nemt ligesom at falde ned i den grøft." ... "Men når man alligevel gør så meget ud af at lave noget flot fysisk, så hænger det vel også sammen med, at man bliver grebet af mulighederne for at lave noget, som man ikke kan i real life. Du kan jo godt lave et flot hus, du behøver ikke tage hensyn til, at materialerne er dyre som man gør i virkeligheden, når du skal have en særligt italiensk marmor."

(interview med Fie)

\begin{abstract}
"Det, ... der undrer mig, også generelt ved Second Life, er at .... man laver jo egentlig bare en afspejling af ting, der er i forvejen ... [det] jeg har imod virtuelle verdener generelt, ...eller synes der er mærkeligt ved dem, det er at vi ... har ... vores egen verden. Hvorfor skal vi så, ... bygge en kopi af den ... for at skabe et ... et rum til ... at interagere i." (interview med Ivan)
\end{abstract}

Der er både svagheder og styrker i at genskabe en nogenlunde konventionel biblioteksbygning i den virtuelle verden. Den væsentlige svaghed er, at man ved at begrænse sig til det velkendte samtidig lægger op til, at de aktiviteter, som udfoldes i rummet, er konventionelle. Dette fremgår til dels også af Info Island DK projektbeskrivelsen, som hovedsageligt opregner en række kendte gøremål, som skal afprøves i Second Life (Borgerservice og Biblioteker, 2007). Projektforløbet kan tolkes som en gradvis frigørelse fra disse bindinger, idet aktiviteterne i løbet af projektet skiftede fokus fra helt overvejende at etablere konventionelle bibliotekstjenester for at fylde rammen ud - $\mathrm{fx}$. at skabe adgang til WWW-ressoucer, opretholde vagtplan - til også at gennemføre arrangementer, som kreativt udnytter mediets fortrin - on-line forfatteraftener, bogdiskussioner og virtuelle ekskursioner (Heilesen, 2010).

Det fremgår af interviews med projektdeltagerne, at de indledningsvis ikke har tænkt synderligt over, at det virtuelle bibliotek var en remediering af det fysiske bibliotek. Der forekommer udsagn som "det så da fint ud" og "det stod der egentlig bare". Der herskede imidlertid ikke tvivl om, at dette 
var et bibliotek, en værdig og til dels velkendt ramme som projektdeltagerne skulle udfylde ved at udvikle et indhold samt i det hele taget at være til stede.

Ved afslutningen af projektet, efter at have arbejdet med og i bygningen, var deltagerne væsentligt mere kritiske. Her lyder der udsagn som "for meget kopi af real life", "traditionelt", "lidt kedeligt", "ikke visionært", "bundet", "lidt hæmmende", "koldt", "minder om et kunstmuseum". Et af de klare vidnesbyrd om, at Formidlingshuset oplevedes mere som kulturpalads end et sted, hvor man gerne vil opholde sig er, at deltagerne som regel henlagde de projektinterne sociale aktiviteter til Ames' Bar. Baren med sit lidt rå udseende og knebne plads udgjorde en mere intim ramme for socialt samvær end de store, stilrene sale i Formidlingshuset. Dertil skal dog føjes, at baren ligger skjult under havet, så deltagerne kunne være nogenlunde uforstyrrede dér.

Trods kritikken er ingen af projektdeltagerne i stand til at anvise et konkret alternativ til biblioteksbygningen. Adspurgt om hvad de ville foretrække, henviser de fleste til stemninger og til udnyttelsen af rummet, men ikke til konkret formgivning: "lege", "leg med 3D-muligheder", "udnytte 3Dmuligheder", "sjovt", "lidt sjovere", "farvestrålende og flot", er almindelige udsagn.

Den mest oplagte styrke ved at tage udgangspunkt i et konventionelt bibliotek er, at biblioteksøen bidrager til at skabe identitet, samtidig med at det er et forankringspunkt, et trygt sted at være i den ukendte virtuelle verden:
"... det jeg tror, det handler om, det er måske betydningen af at have et ikon på et bibliotek, i virkeligheden. Det at have en bygning, et sted man identificerer som biblioteket, det at have et stærkt visuelt udtryk som signalerer noget, .... det tror jeg stadigvæk er en vigtig ting ..." (interview med Dorte)

\begin{abstract}
"Men jeg synes da nok, at det er vigtigt, at der er et fysisk sted, hvor man tager udgangspunkt, altså, at der er her, vi er. Jeg synes ikke, at vi kunne have været der som institution, hvis vi alle sammen bare rendte rundt og var avatarer, og være alle mulige forskellige steder. Jeg synes, det er vigtigt, at der en eller anden form for lokalitet, som man tager udgangspunkt i." (interview med Anne)

"... altså man er jo nødt til at starte et sted, og så er det jo meget naturligt at starte i den verden, man kender. Altså, hvad skal vi have som det første, vi skal vel have et sted at være."

(interview med Carl)
\end{abstract}

Dorthe, som også giver udtryk for betydelig faglig stolthed - "Det kan godt give en vis respekt, at man er biblioteksavatar derinde" - udtrykker i citatet meget præcist opfattelsen af, at biblioteket, repræsenteret ved et fornemt bygningsværk, er et symbol på kultur og et samlingspunkt. Anne og Carl taler mere praktisk om at have et forankringspunkt, og den anskuelse 
tilslutter de øvrige interviewede sig. Begge omtaler øen som "et sted" og tolker dermed det virtuelle bibliotek som en lokalitet og ikke bare en service. Dette stemmer overens med, at mange af informanterne benytter ordet "derinde", når de omtaler deres aktiviteter i Second Life.

Flere af deltagerne har forestillet sig Info Island DK som det naturlige startpunkt for danske brugere af Second Life, en art portal til den virtuelle verdens tilbud. En sådan portal kræver selvfølgelig en passende markering, og når denne skal være rumlig og tryg, er intet vel mere naturligt end en bygning. Det er ikke tilfældigt, at web-browsernes standardikon for "hjem" er et billede af et hus.

Tolket i et bredere perspektiv giver Carls udsagn udtryk for noget basalt i højkulturer: Civilisation - afledt af det latinske civis, "borger i en by styret af love"- skabes ved at afgrænse sig fra naturen og skabe orden inden for indhegningen. Det er en historie, som gentager sig som en tilfredsstillende leg, hver gang en Second Life indbygger erhverver land og giver sig i kast med opdele vildmarken med mure og hegn.

Selv om en enkelt eller to af projektdeltagerne medgiver, at alle bibliotekets services godt kunne have været udbudt på en virtuel græsplæne, så opleves det som vigtigt og rigtigt at have en passende ramme for aktiviteterne. Det understreger deres betydning, og det spiller en rolle for den enkeltes fortolkning af situation. For eksempel er det ikke ligegyldigt, hvor man afholder et møde:

\section{"... det gav måske et mere formelt præg, at det var i sådan et mødelokale, fordi man ligesom sad ned ... ikke bare stod og hang ude på en græsplæne ... Det kan godt ske, der har været et eller andet, der måske kan være noget psykisk i det, at man ligesom siger, nu er vi i et mødelokale, nu skal vi være ... Udenfor, så begynder folk lige pludselig at flyve ud ..." (interview med Ivan)}

\section{Typer af virtuelle biblioteker}

Second Life evangelisten John Lester (2008) skelner mellem gengivelser af den fysiske virkelighed (reality), kommende virkelighed (soon to be reality, fx. modeller af arkitektur), den uhåndgribelige virkelighed (intangible reality, fx. visualiseringer af molekyler), og forestillet virkelighed (imaginative reality). Info Island DK er et eksempel på forestillet virkelighed, fordi der ikke findes et konkret forlæg for bygningen i den fysiske verden. Men der er tale om en virkelighedsnær udfoldelse af fantasien, i og med at bygningen stort set ville kunne opføres i den fysiske verden, blot med teleporteren erstattet af en elevator. Friluftsauditoriet midt $\mathrm{i}$ bygningen er således blot et atrium, og hele konstruktionen rummer antydninger af den elizabethanske teaterbygning, som den kendes fra fx. Shakespeares Globe Theatre. 

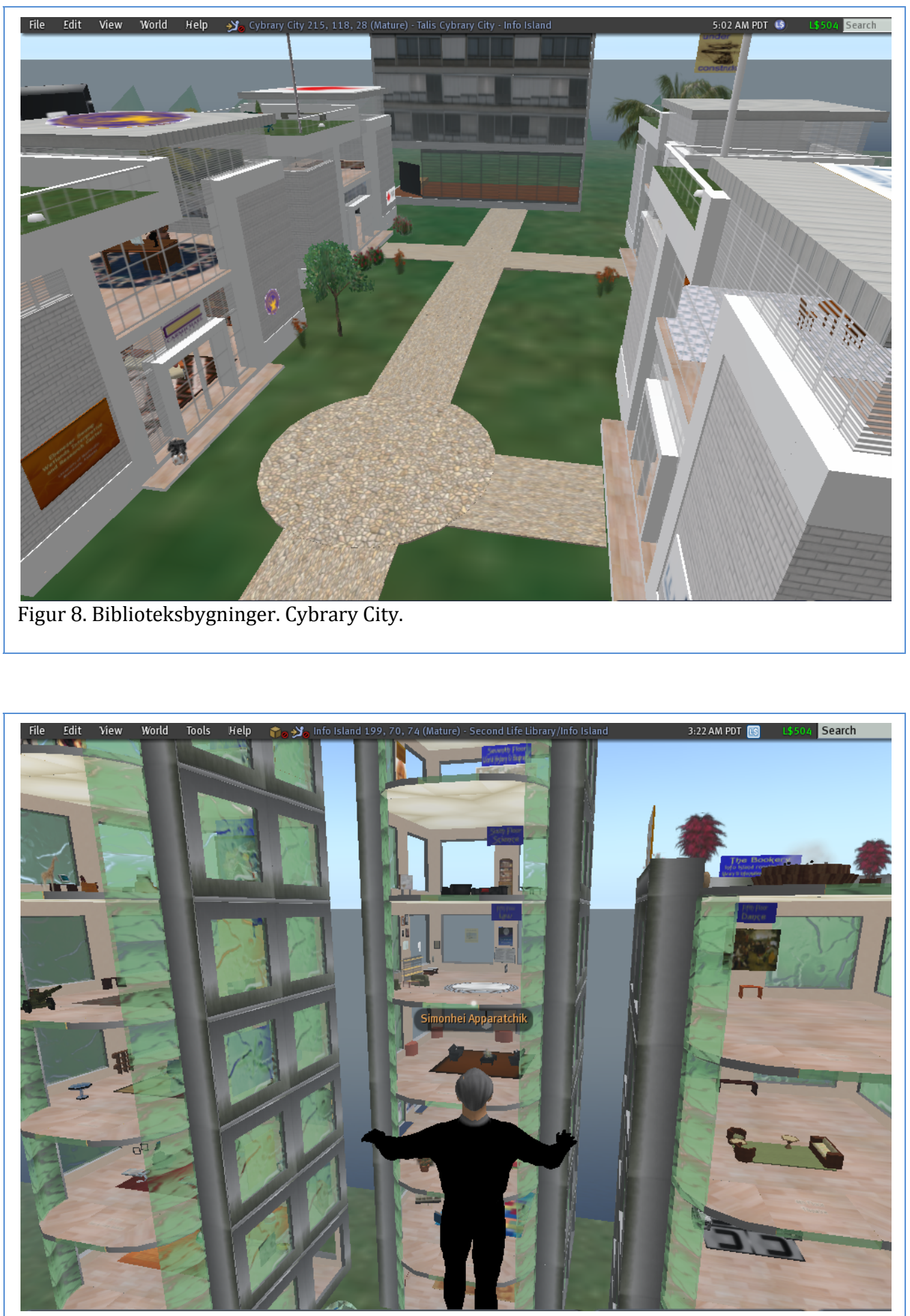

Figur 9. Bell Library Towers. Info Island.

Den beherskede, forestillede virkelighed er kendetegnende for de virtuelle biblioteker i Information Archipelago. De efterligner gerne den fysiske verdens bygninger og gør det sommetider for slavisk. Som nævnt er der ikke brug for trapper i Second Life. Det giver heller ikke mening at have døre, der skal åbnes, eller at opdele bygningen i en labyrint af rum med uigennemtrængelige skillevægge, eller for den sags skyld at lægge tag på husene i en virtuel verden, hvor det hverken stormer, regner eller sner. Til 
tider virker det som om, der er tænkt meget lidt over designet af biblioteksbygningerne. Som eksempel kan nævnes byggeriet i kvarterer af Cybrary City, hvor de anonyme, ens kontorbygninger ligger tæt, og hvor det eneste tydeligt biblioteksagtige er navneskiltet på facaden (Figur 8).

Inden for den forestillede virkeligheds biblioteksbyggeri i Second Life forekommer der to retninger, som gør op med forestillingen om, at den virtuelle bygning skal ligne en biblioteksbygning, så meget det nu kan lade sig gøre, når man bygger med prims (geometriske grundformer) i stedet for mursten. Den ene satser på funktionalitet, den anden på tematisering.

Det funktionelle bibliotek er konstrueret med henblik på at give brugeren let adgang til bygningen samt at gøre det nemt at overskue, hvad den indeholder. I Bell Library Towers på Info Island er der således opnået glimrende funktionalitet ved blot at fjerne facaden på bygningsværkets tårne, så etagerne, hver med sit bestemte emne markeret visuelt ved hjælp af inventaret, er lette at gå til og nemme at overskue, når brugeren lader sin avatar svæve langs forsiden af bygningen (Figur 9). Det giver nogenlunde samme funktionalitet, som man opnår med en drop-down menu i en grafisk brugergrænseflade, hvor musen føres hen over menupunkterne, indtil et af dem vælges med et klik.

Vestfold Fylkeskommunes virtuelle bibliotek på Infotainment-øen i Info Island DK blev nedlagt i efteråret 2008 efter blot et år i Second Life. Det var udformet som en halvcirkelformet bygning, hvis flade side var blotlagt, så der var fri adgang til at se og besøge de to etager (samt det flade tag), designet som åben-plan ringe omkring et væksthus i bygningens centrum (Figur 10). Der var kælet for detaljerne, så bygningen virkede smuk og indbydende at færdes i på trods af "afgrunden" for enden af etagen.

En langt mere rå funktionalitet finder man i Alliance Library på Info Island. Her er kun opført de bærende konstruktioner og etageadskillelserne. Vægge, vinduer og døre mangler, og taget er gennembrudt, så der fra alle sider er frit indsyn og fri adgang til begge den L-formede bygnings etager. Den indvendige rumopdeling minder om et kontorlandskab. Partitionerne er skitseret med hoftehøje skillevægge, plakater og tavler, og det er derfor muligt at overskue store dele af etagen fra midtergangen. Opdelingerne tjener det praktiske formål at adskille de forskellige emnekategorier, brugeren kan opsøge, uden at lægge hindringer i vejen for hans færden i bygningen (Figur 11).

Den ultimative funktionalitet opnås ved at fjerne biblioteksbygningen helt og stille biblioteksressourcerne frem under åben himmel. Det har man gjort på ALA Island, hvor der kun er gulvet tilbage af biblioteksbygningen (Figur 12). Det er så til gengæld brugt til at skabe orden og systematik. Der skelnes tydeligt mellem natur og kultur (veje og terrasser), og det er på disse sidste, ressourcerne er opstillet. Således er der bevaret en illusion af afgrænset rum, og det fremhæves sært nok ved, at flere af terrasserne trodser tyngdekraften og svæver i rummet. Nok mangler væggene, men oplevelsen af rumafgrænsning er intakt, fordi avataren styrter ned, hvis den trodser designets logik. 

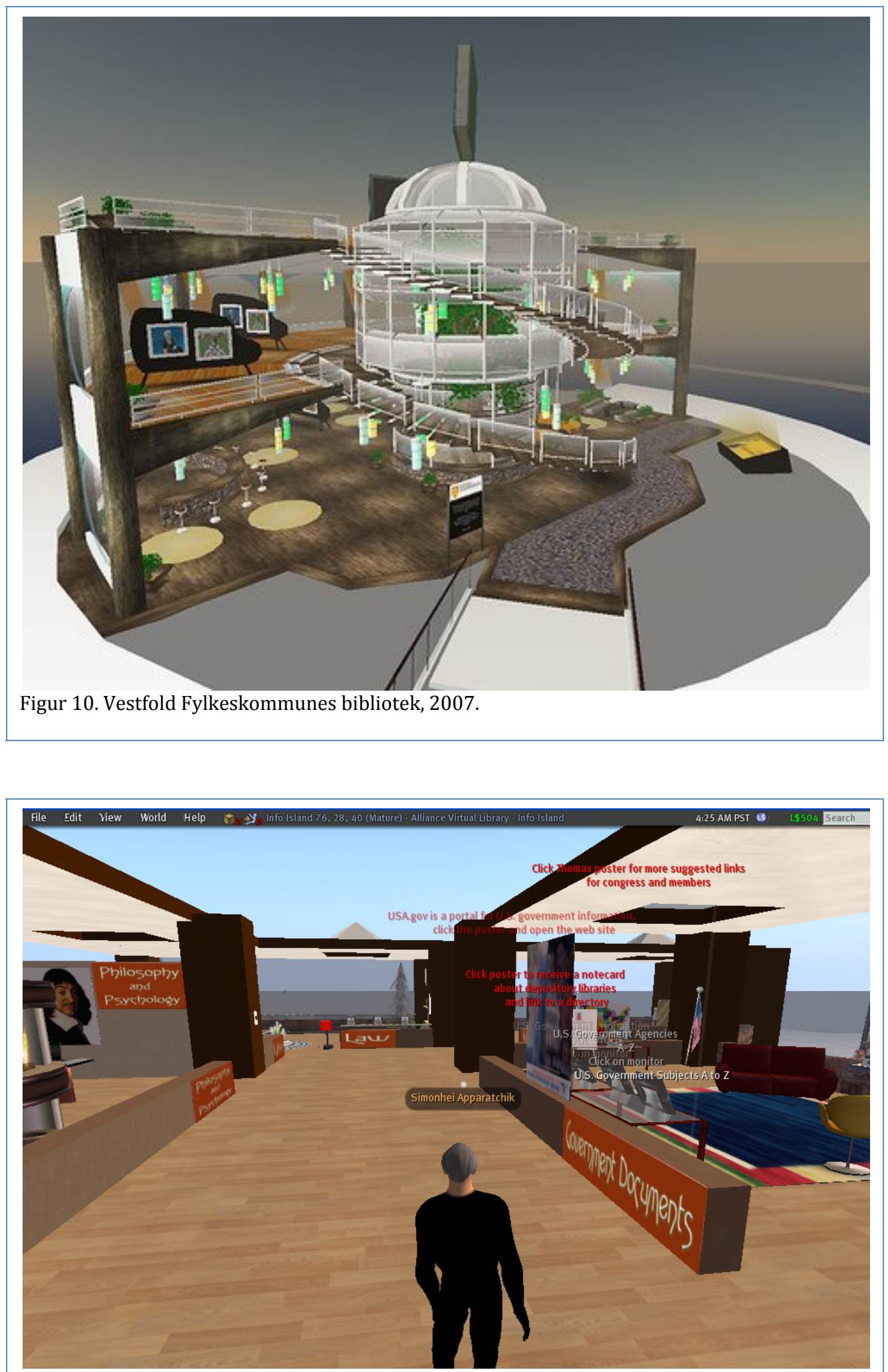

Figur 11. Alliance Library, første sal. Info Island..

Den tematiske retning inden for det virtuelle biblioteksbyggeri anvender design som et indexikalsk tegn. Der kan skelnes mellem huse, som henviser til bestemte emner, og huse, der henviser til bestemte genrer eller litterære traditioner. Fælles for dem alle er, at de skaber en stemning og sætter gang 
i associationer, der er knyttet til bibliotekets produkter snarere end til biblioteket som institution. De fleste af denne type bygninger indgår som dele i en helhed, som en slags afdelinger i en samling, der afgrænses af den $\emptyset$, de er anbragt på, og som ikke nødvendigvis kan henføres til ét bestemt bibliotek i den fysiske verden.

Den amerikanske Info Island byder på en stribe gode eksempler på begge tematiske retninger. Centralt på øen ligger Peace Garden, som er en ressource om religion. I haven er opført en nogle små huse, som hver især er udformet som typiske religiøse bygningsværker: En kirke, en moské, et japansk buddhisttempel, en synagoge og et hindualter (Figur 13). For den bruger, som kender de religiøse arkitekturs koder, er det en smal sag at søge hen til den bygning/religion, man ønsker information om. Bygningernes grundareal er lille. De er ikke mødesteder, men derimod menupunkter i Info Islands store grafiske menu.

Tæt ved Peace Garden er opført to virtuelle bygninger, som henviser til hver sin litterære genre (Figur 14). Mystery Manor skal således forestille et engelsk hus på landet, og ingen ynder af krimi-genren vil være i tvivl om, at der gemmer sig ugerninger bag stokroseidyllen. Den anden bygning, som ligner en mellemting mellem et vandtårn og en UFO, rummer Talis SciFi \& Fantasy Portal, der tilbyder ressourcer inden for disse to litterære genrer.

Endelig skal nævnes virtuelle biblioteker, der tilbyder information om national litteratur og som markerer dette gennem bygninger i en arkitektur, der er karakteristisk for pågældende land. Det er ikke biblioteksbygninger i vanlig forstand, men blot mere eller mindre typiske, traditionelle bygninger. De fleste af disse bygninger er at finde på Info Island International, der udgør en art litterær verdensudstilling. Her ligger et træhus fra Astrid Lindgreens Skåne side om side med et tysk funkisbyggeri, et luftigt sydkinesisk tårn, en mexicansk hacienda, en japansk have, med mere (Figur 15).

Ud over bygningsværker som visualiserer forestillet virkelighed, forekommer i Second Life også nogle eksempler på gengivelser af den fysiske virkelighed. Et af de spektakulære af slagsen er Cleveland Public Library, opført 1925, hvis hovedbygning i florentisk-klassisk stil er genskabt i den virtuelle verden, komplet med søjler, indlagte marmorgulve og en overdådig kuppeludsmykning (Figur 16). I dette tilfælde tjener den virtuelle reproduktion til at illustrere bibliotekets betydning, lidt på samme måde som pragtbygningen på Info Island DK.

Modeller, enten som gengivelse af fysisk virkelighed eller af en kommende virkelighed (planlagt bygning) er imidlertid oplagte at bruge til træning af ansatte og brugere og til forsøg med indretning, foruden til kollaborativ udvikling (se fx. Schultz \& Brouchoud, 2007). Et par af Info Island DK informanterne er inde på, at det netop kunne have været spændende at afprøve projekteret byggeri af to nye danske biblioteker i stedet for at arbejde med en fantasibygning. Men det var ikke en af projektets opgaver, og en gennemgang af Information Archipelago har heller ikke godtgjort, at nogen at de øvrige virtuelle biblioteker i området benyttes på denne måde. 

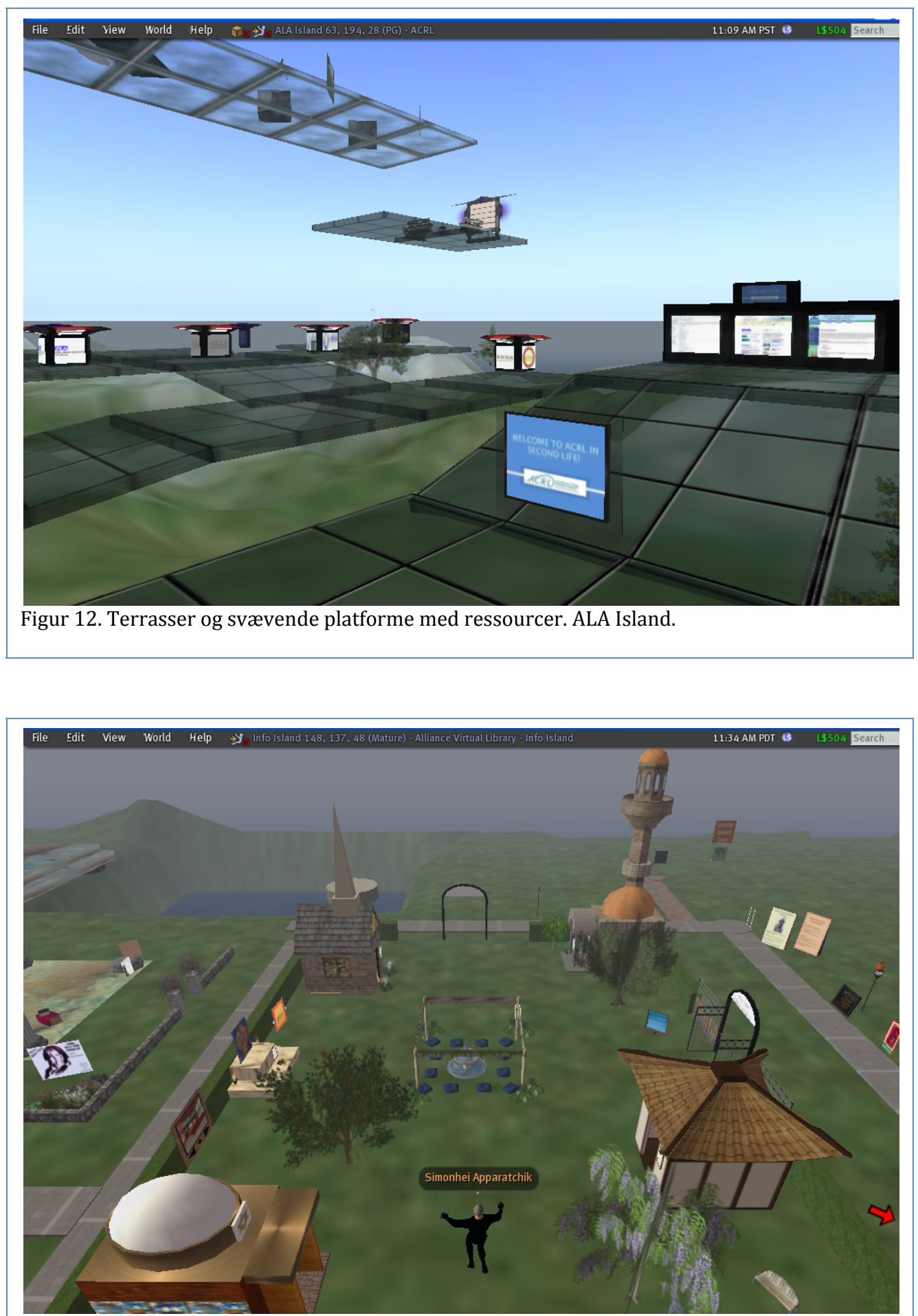

Figur 13. Peace Park. Info Island. En 3-D menu for ressourcer om religion. 


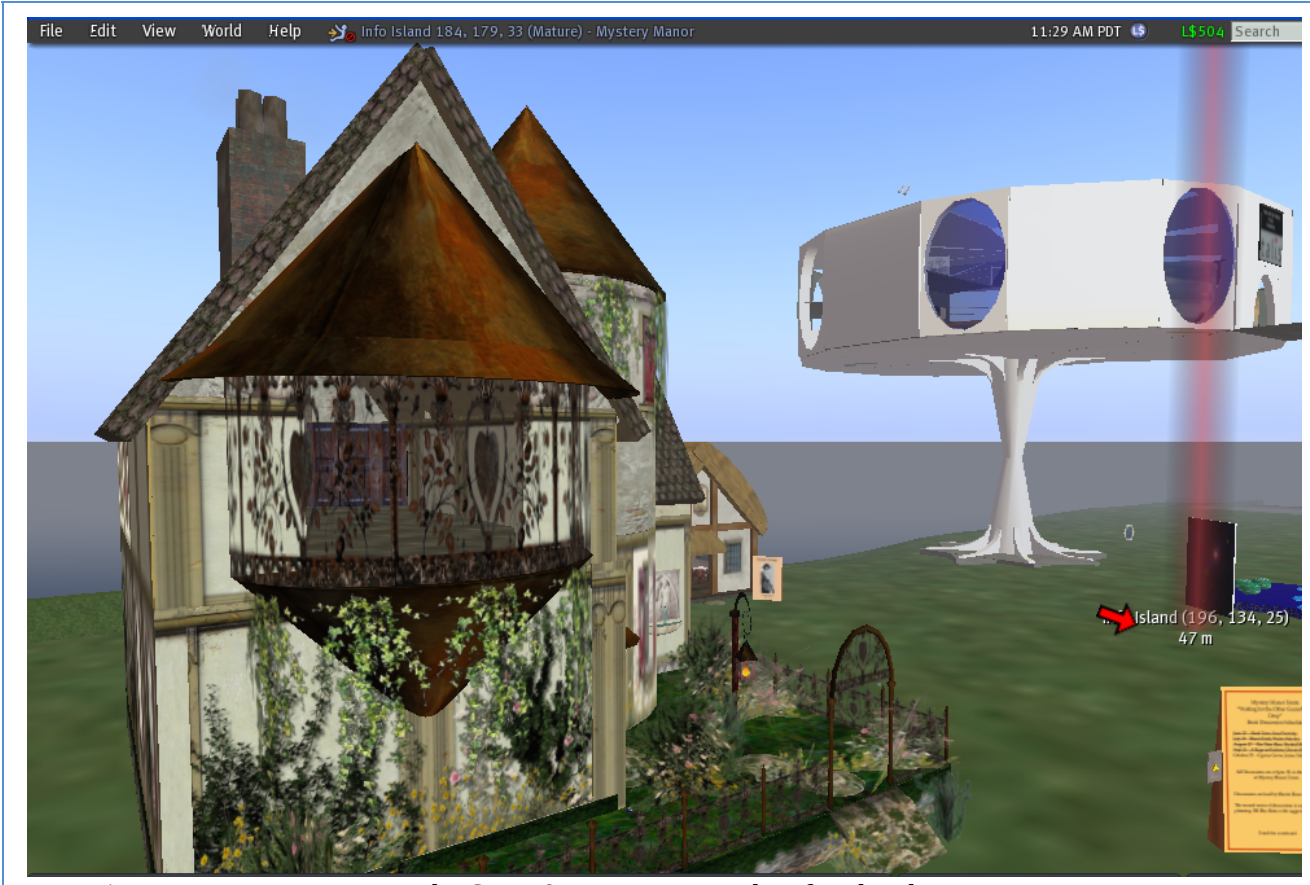

Figur 14. Mystery Manor og Talis SciFi \& Fantasy Portal. Info Island.

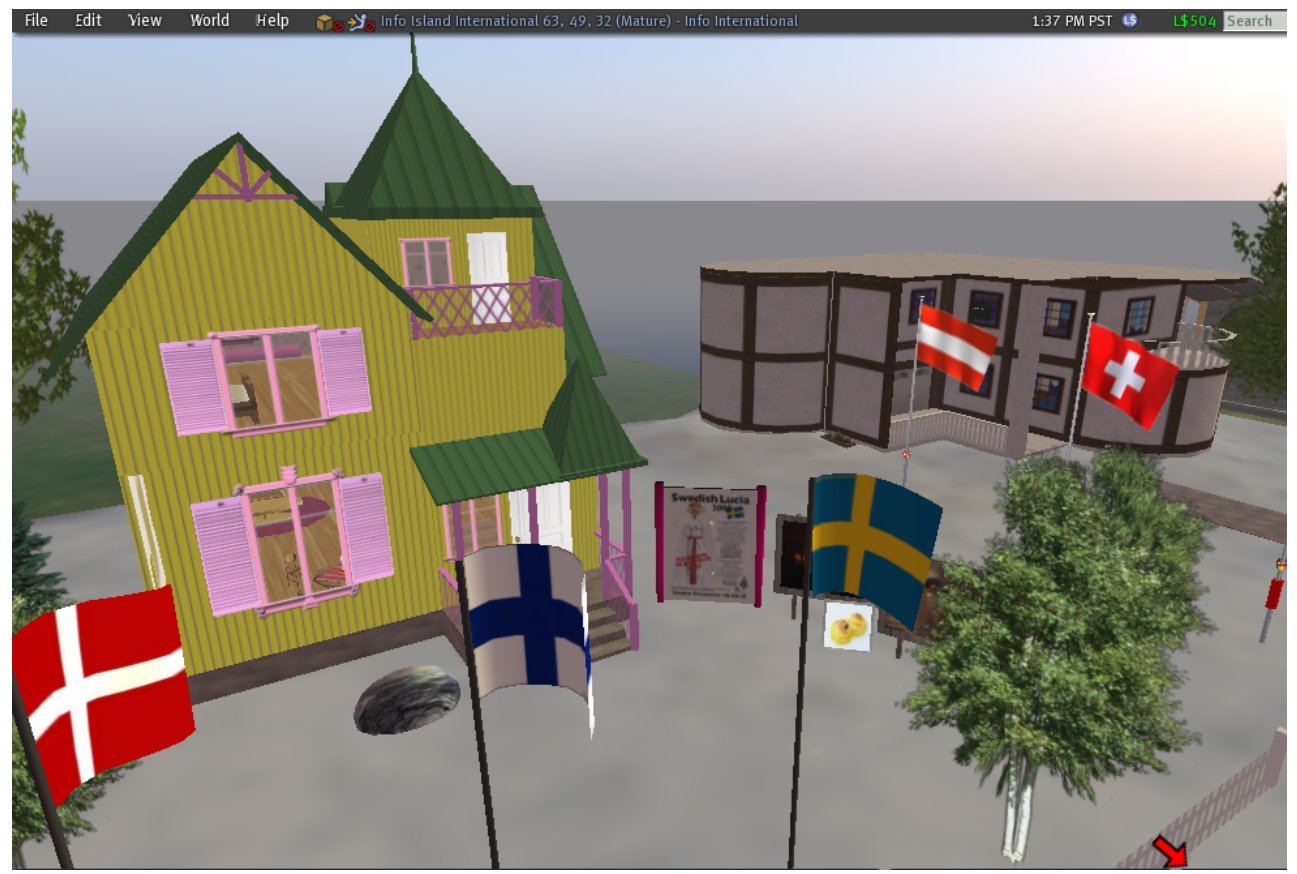

Figur 15. Det nordiske og det tyske bibliotek. Info Island International. 


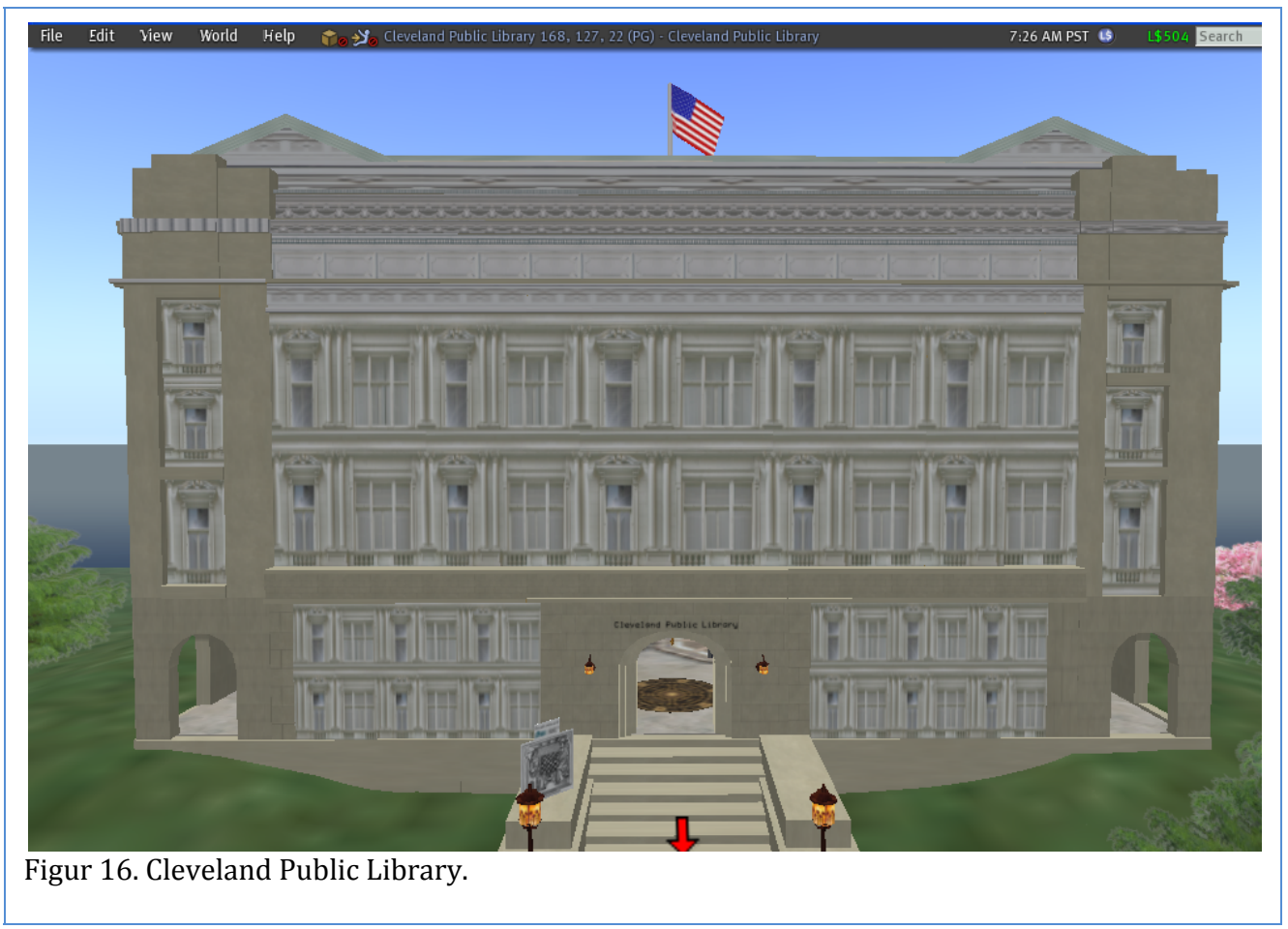

\section{Konklusion}

Det ligger i mediets natur, at det, der skal opleves i Second Life, nødvendigvis skal visualiseres. Det virtuelle bibliotek, som tilbyder forskellige services, skal derfor også have en form. En bygning er det foretrukne valg, og det er da også lettere at visualisere et hus, end det er at visualisere en service. Men med dette valg følger en forpligtende metafor, som sætter grænser for såvel udviklernes, bibliotekarernes og brugernes udfoldelsesmuligheder.

Der er ret stor spændvidde i udformningen af bygningerne. Nogle, blandt andet det danske Info Island DK, har valgt at tænke det virtuelle bibliotek som en pendant til den fysiske verdens bibliotek og har dermed skabt en ramme om aktiviteterne, som uvægerligt er med til at præge brugernes opfattelse af de aktiviteter, der foregår i biblioteket. Andre har nedtonet betydningen af selve bygningen ved at tilføre den virtuelle husmodel funktionalitet gennem et design, der i et eller andet omfang signalerer de services, den konkrete bygning byder på - fx. katalog og specialsamling. Men også den form for bygninger er gennem formgivningen med til at stemme brugernes forventninger.

Fælles for alle de besøgte biblioteker er, at de har valgt at iscenesætte sig selv som konventionelle biblioteker i den forstand, at de har bestemt sig for at være "steder", brugeren skal opsøge. Som tidligere nævnt understreges stedsligheden af, at mange biblioteker har valgt at klumpe sig sammen i ét lille område af den virtuelle verden. Dermed har man dels afskåret sig fra at eksperimentere med at bringe biblioteket ind i ukonventionelle arbejds- og fritidssammenhænge, dels har man betonet, at biblioteksfunktioner foregår i et til formålet afgrænset rum. På dette punkt kan Second Life 
bibliotekerne ses som et tilbageskridt i forhold til det allestedsnærværende virtuelle bibliotek, som med stort held er realiseret på World Wide Web.

En næste generation af biblioteket i den virtuelle verden vil måske forsøge at gøre op med rollen som institution med særlig lokalitet og byggeri og drage nytten af læren fra netbiblioteket, at det ikke er biblioteket som sådan, men derimod bibliotekets funktioner der er efterspurgte, og som har givet biblioteket nyt liv og en ny mission i informationssamfundet.

\section{Litteratur}

Aarseth, E. (1996). Virtuell virkelighet og retorikk - en kritikk av virtualitetsbegrepet. Retrieved December 15, 2008, from http://www.hf.uib.no/hi/espen/VV-retorikk.html.

Anders, P. (1999). Envisioning Cyberspace : Designing 3D Electronic Spaces. New York: McGraw-Hill.

Bachhofer, L. (1946). A Short History of Chinese Art. [New York]: Pantheon.

Barlach, G. (2008). Projektafslutningsrapport for Info Island DK. Århus: Kultur og Borgersevice. Retrieved July 7, 2008, from http://www.aakb.dk/sw207.asp.

Barlach, G., \& Larsen, D. B. (Writer) (2008). Info Island DK. In IT og Kommunikation Kultur og Borgerservice Århus Kommune (Producer). Århus. Retrieved July 17, 2008, from http://www.bibstream.dk/default.aspx?aid=1068\&lid=21\&bhcp=1.

Bell, L., Peters, T., \& Pope, K. (2007). GET A (SECOND) LIFE! Computers in Libraries, 27(1), 10 - 15.

Bell, L., Lindbloom, M.-C., Peters, T., \& Pope, K. (2008). Virtual Libraries and Education in Virtual Worlds: Twenty-first Century Library Services. Policy Futures in Education, 6(1), 49 - 58.

Borgerservice og Biblioteker. (2007). Justeret Projektbeskrivelse. Info Island DK. Bibliotekerne i Second Life. Århus: Borgerservice og Biblioteker, Kultur og Borgerservice, IT og Kommunikation. Retrieved July 13, 2008, from http://www.aakb.dk/sw207.asp.

Cooper, A. (2003). About face 2.0: The Essentials of Interaction Design. Indianapolis, IN: Wiley.

Dodge, M., \& Kitchin, R. (2001). The Atlas of Cyberspace. Harlow, England ; New York: Addison-Wesley.

Gibson, W. (1984). Neuromancer. New York: Ace Books.

Goffman, E. (1974). Frame Analysis : an Essay on the Organization of Experience. New York: Harper \& Row.

Gombrich, E. H. (1960). Art and Illusion : a Study in the Psychology of Pictorial Representation. New York: Pantheon Books. 
Gotved, S. (2008). Evaluering af projektet Info Island DK. København: Vilen. Retrieved July 7, 2008, http://www.aakb.dk/graphics/portal/ bibliotekerne/ evaluering_VILEN_080421.pdf.

Hald, B. (2007). Info island DK - i Second Life. Bib Forum for bibliotekerne $i$ Frederiksborg Amt og Københavns Amt(Juni 2007), 18.

Hald, B. (2008). Info Island DK - dansk bibliotek i Second Life. Bib Forum for bibliotekerne i Region Hovedstaden, 2008(Juni), 16-17.

Heilesen, S. (2008). Case-beskrivelse: Info Island DK. Sense-making strategies and user-driven innovations in virtual worlds Working Papers; 2. Roskilde: Roskilde University. Retrieved December 20, 2008, from http://rudar.ruc.dk/handle/1800/3360.

Heilesen, S. B. (2009). Remediating Cultural Services in Second Life: The case of Info Island DK. First Monday, 16(6).

Heilesen, S. B. (2010). Teleporting the Library? Journal of Gaming \& Virtual Worlds, 2(1), in press.

Knudsen, C., \& Olsen, N. A. (2008). Virtuelle Verdener. Retrieved July 20, 2008, from

http://www.kb.dk/da/kub/projekter/metaverses/index.html.

Lester, J. (2008, August 6). Virtual Worlds, Real People. Paper presented at the Association for Education in Journalism and Mass Communication (AEJMC) Conference, Chicago, IL. Retrieved December 20, 2008, from http://zero.hastypastry.net/pathfinder/public_slides/aejmc.ppt.

Mortensen, W. L. (2007). Biblioteksbesøg i Second Life. Bib Forum for bibliotekerne i Frederiksborg Amt og Københavns Amt(Juni 2007), 19.

Pedersen, T. N. (2007a). Hands-on i Second Life: Matrix-solbriller og lidt for korte kakishorts. Bibliotekspressen, 2007(15), 6-7.

Pedersen, T. N. (2007a). Midtvejskrise: Virtuel Verden skal ud af vuggen. Bibliotekspressen, 2007(15), 8.

Qvortrup, L. (2002). Virtual Space : Spatiality in Virtual Inhabited 3D Worlds. London; New York: Springer.

Schultz, R., \& Brouchoud, J. (2007). Studio Wikitecture: Opening Architecture. Retrieved December 20, 2008, from http://studiowikitecture.wordpress.com/.

Second Life Library Project. (2008). Alliance Virtual Library. www.infoisland.org. Infoisland Archipelago \& Beyond! Retrieved December 16, 2008, from http://infoisland.org/directory/.

Snowdon, D. N., Churchill, E. F., \& Frecon, E. (2004). Inhabited Information Spaces : Living with your Data. London ; New York: Springer.

Tække, J. (2008). Internettet som resten af verden. Semikolon, 8(16), 36 45. 
Wikipedia. (2008). Cyberspace. Retrieved December 12, 2008, from http://en.wikipedia.org/wiki/Cyberspace. 